\title{
Withania somnifera Ameliorates Aluminium Chloride-induced Testicular Toxicity and Impaired Fertility in Mus musculus
}

\author{
P. KUMAR AND POONAM SINGH ${ }^{1 *}$
}

Department of Zoology, Bihar National College, Patna University, Patna-800 004, ${ }^{1}$ Departments of Zoology, MMV, Banaras Hindu University, Varanasi-221 005, India

Kumar and Singh: Role of Withania somnifera in $\mathrm{AlCl}_{3}$-induced reproductive toxicity

\begin{abstract}
The present study was planned to evaluate the effectiveness of Withania somnifera against aluminium chloride-induced testicular toxicity and impaired fertility. Swiss mice were divided into 6 groups of 12 each. Mice of group I served as control while that of group II were administered with $\mathrm{AlCl}_{3}(100 \mathrm{mg} / \mathrm{kg} /$ day) for 30 consecutive days. Animals of group III were administered with $\mathrm{AlCl}_{3}(100 \mathrm{mg} / \mathrm{kg} / \mathrm{day})$ for 30 consecutive days followed by sacrificing the animals 42 days after withdrawal of the treatment. Mice of groups IV, V and VI were administered with Withania somnifera $(200 \mathrm{mg} / \mathrm{kg} / \mathrm{day})$ only, $\mathrm{AlCl}_{3}(100 \mathrm{mg} /$ $\mathrm{kg} / \mathrm{day})$ along with Withania somnifera $(100 \mathrm{mg} / \mathrm{kg} / \mathrm{day})$ and $\mathrm{AlCl}_{3}(100 \mathrm{mg} / \mathrm{kg} / \mathrm{day})$ along with Withania somnifera $(200 \mathrm{mg} / \mathrm{kg} / \mathrm{day})$, respectively, for 30 consecutive days. $\mathrm{AlCl}_{3}$-induced noticeable alterations in the body weight, testicular weight, histoarchitechture of the testis, aluminium accumulation, level of LPO, activities of antioxidant enzymes, functional markers, concentration of cholesterol, level of serum testosterone and mating ability were restored markedly in the mice co-administered with either 100 or 200 $\mathrm{mg} / \mathrm{kg} / \mathrm{day} \mathrm{AlCl}_{3}$. These findings thus revealed the ameliorating potential of Withania somnifera against aluminium chloride-induced testicular toxicity and impaired fertility.
\end{abstract}

Key words: Withania somnifera, aluminium chloride, testis, infertility

Infertility is a major health issue contributed equally by the men and women of the reproductive age. There are various factors causing infertility like genetic, hormonal, anatomical and environmental that may result in damage of the reproductive tissue and alterations in the gamete quality in the males and as well as in the females. Among the environmental factors, exposure of certain metals to the men working in factories has been reported to cause tremendous deterioration in their reproductive health, resulting in the state of infertility ${ }^{[1-3]}$. Aluminium is an ubiquitous, most prevalent metal and the third most important abundant element in the earth's crust after oxygen and silicon. Its exposure in excessive amount leads to accumulation in target organs and damage to various organs in both humans and animals. Aluminium has been reported to cause neurotoxicity ${ }^{[4-6]}$, hematotoxicity ${ }^{[7]}$, hepatotoxicity ${ }^{[8,9]}$, nephrotoxicity ${ }^{[10]}$ and reproductive toxicity ${ }^{[11-14]}$. Several animal studies have reported that administration of $\mathrm{AlCl}_{3}$ at various doses and durations impaired the fertility in males directly by inhibiting the sperm or testicular function

*Address for correspondence

E-mail: poonom@gmail.com

May-June 2020 or indirectly by impairing the hypothalamic-pituitarytesticular axis resulting in low production of testosterone and poor semen quality ${ }^{[1-19]}$. A previous study reported marked alterations in the histoarchitecture of the testis and seminal vesicle along with significant alterations in the sperm parameters, serum testosterone, LPO, antioxidant enzymes and fertility of the Swiss mice, administered with $\mathrm{AlCl}_{3}$ at the dose of $100 \mathrm{mg} / \mathrm{kg} / \mathrm{d}^{[20]}$. Earlier findings reported the marked increase in metal accumulation and alterations in functional markers in the testis of the mice administered with the same dose of $\mathrm{AlCl}_{3}^{[21]}$.

Now a days, there has been a tremendous increase in the awareness of medicinal plants, used as supplements

\footnotetext{
This is an open access article distributed under the terms of the Creative Commons Attribution-NonCommercial-ShareAlike 3.0 License, which allows others to remix, tweak, and build upon the work non-commercially, as long as the author is credited and the new creations are licensed under the identical terms
} Indian J Pharm Sci 2020;82(3):398-408 
or therapeutic agents against various health issues. Since these are natural and relatively safe with minimum or no side-effects, hence being preferred by most of the people worldwide ${ }^{[22]}$. Withania somnifera, family Solanaceae, is one of the important and popular medicinal plant of geriatric tonics mentioned in Indian systems of Ayurvedic medicine. In Ayurveda, this plant is claimed to possess potent aphrodisiac, rejuvenative and life prolonging properties ${ }^{[23]}$. It contains number of phytoconstituents in which withanolide, a steroidal saponin, is the major active component. W. somnifera has also been known for its potent antioxidant and free radical quenching properties because of the presence of withaferin A, a glycowithanolide ${ }^{[24]}$. Steroidal and antioxidant properties of $W$. somnifera raise the scope for the use of various parts of this plant in infertility therapy. Administration of root extract of $W$. somnifera increased the levels of serum testosterone and $\mathrm{LH}$ significantly in infertile men ${ }^{[25]}$. It also improved semen quality in stress-induced male infertility ${ }^{[26]}$. Further, it was reported to inhibit lipid peroxidation and to reduce oxidative stress in rat ${ }^{[24]}$, mouse ${ }^{[25]}$ and man ${ }^{[27]}$. Efficacy of $W$. somnifera has also been reported under certain experimental conditions as it protected testicular injuries from ROS and avoids infertility in galactose-stressed mouse ${ }^{[28]}$. In addition, its root extract also protected the testis from injury by reducing oxidative stress in the rat, induced by cadmium ${ }^{[29]}$, $\operatorname{arsenic}^{[30]}$ and ethanol ${ }^{[31]}$. The ameliorating potential of $W$. somnifera has also been reported against delayed response of epididymal sperm characteristics and testicular oxidative stress induced by ethylene glycol monomethyl ether (EGME) in the mouse ${ }^{[32]}$. In view of beneficial properties of $W$. somnifera, the present study was designed to evaluate its effectiveness against $\mathrm{AlCl}_{3}$-induced testicular injury and impaired fertility in the laboratory mouse.

\section{MATERIALS AND METHODS}

\section{Plant, extract preparation and phytochemical analysis:}

Roots of $W$. somnifera were purchased from the local market of Varanasi and verified from the Department of Botany, Banaras Hindu University (Voucher specimen no.Solana.2016/2). The ethanol root extract was prepared using the protocol of Ansari et al. ${ }^{[33]}$ with some modifications. The roots of $W$. somnifera were rinsed with water, air dried, powdered and extracted with $70 \%$ ethanol (1:10) in a Soxhlet apparatus and evaporated to dryness in a rotary evaporator on a boiling water bath at $60^{\circ}$. The extract was then stored at $4^{\circ}$ in air tight containers separately and a required amount was dissolved in distilled water for the treatment as and when necessary. Presence of saponin and flavonoids were tested in the root extract of $W$. somnifera by adapting the method of Edeoga et al. ${ }^{[34]}$.

\section{Experimental animals:}

Healthy adult Swiss male mice ( $12 \mathrm{w}$ old) obtained from Animal House, IMS, BHU, Varanasi, weighing 20-30 g were used in the present study. The mice were maintained and handled in animal house as per the recommendation from Central Animal Ethical Committee of the University (CAECU). Approval was obtained from the Animal Ethical Committee, BHU, Varanasi (F.Sc./IAEC/2014-15/0333). The animals were housed in animal cages on paddy husk bedding, in a room with controlled temperature $\left(25 \pm 1^{\circ}\right)$ and lighting ( $12 \mathrm{~h}$ light and $12 \mathrm{~h}$ dark) and fed with standard pelleted food and drinking water ad libitum.

\section{Experimental design:}

After acclimatization, the mice were randomly divided into 6 groups of 12 each. Group I-vehicle-treated control (distilled water); group II- administered $\mathrm{AlCl}_{3} \quad(100 \mathrm{mg} / \mathrm{kg} / \mathrm{d})$ for 30 consecutive days (Al 100); group III- administered $\mathrm{AlCl}_{3}$ (100 mg/ $\mathrm{kg} / \mathrm{d}$ ) for 30 consecutive days followed by sacrificing the animals $42 \mathrm{~d}$ after withdrawal of the treatment (A1 100*); group IV- administered $W$. somnifera $(200 \mathrm{mg} / \mathrm{kg} / \mathrm{d}$ ) for 30 consecutive days (W. somnifera 200); group $\mathrm{V}$ - administered $\mathrm{AlCl}_{3}(100 \mathrm{mg} / \mathrm{kg} / \mathrm{d})$ and $W$. somnifera $(100 \mathrm{mg} / \mathrm{kg} / \mathrm{d})$ for 30 consecutive days (Al 100+W. somnifera 100); group VI- administered $\mathrm{AlCl}_{3}(100 \mathrm{mg} / \mathrm{kg} / \mathrm{d})$ and $W$. somnifera $(200 \mathrm{mg} / \mathrm{kg} / \mathrm{d})$ for 30 consecutive days (Al 100+W. somnifera 200 ). Twenty four hours after the last treatment, final body weights of the animals were recorded followed by sacrificing them by euthenization. Testes of both sides were dissected out, washed in normal saline and processed. Testes of one side were fixed in Bouin's fluid for histological study while that of another side were fixed at $-80^{\circ}$ for biochemical studies.

\section{Testicular weight and histology:}

Wet weight of the testes from each group of the mice was recorded to the nearest $\mathrm{mg}$ on a microbalance to calculate the gonado-somatic index using the following formula. Relative weight $=$ gonad weight/total body weight $\times 100$. Bouin's fixed testis was dehydrated in graded series of ethanol, absolute alcohol, 90, 70, 50, $30 \%$ alcohol and water for $10 \mathrm{~min}$ in each, cleared 
in xylene and embedded in paraffin wax. Sections of $5 \mu \mathrm{m}$ thickness were cut with the help of microtome and stained with periodic-acid-Schiff (PAS) reagent followed by counterstaining with Harris haematoxylin. The stained sections were observed under light microscope.

\section{Metal estimation:}

To determine the aluminium accumulation, testes were weighed and then digested in an aqua regia, diluted with distilled water, made the total volume to $10 \mathrm{ml}$ and then read by inductively coupled plasma mass spectrometer (ICP-MS, model no. iCAP 6200, Thermo Fisher).

\section{Oxidative stress and testicular functional markers:}

The supernatants of $10 \%$ testicular homogenates from all groups were divided into 4 parts, as per requirement. The supernatants were used for the estimation of the level of malondialdehyde (MDA) and the activities of superoxide dismutase (SOD), catalase (CAT) and glutathione peroxidase (GPx) following the methods of Okhawa et al. ${ }^{[35]}$, Marklund and Marklund ${ }^{[36]}$, Claiborne ${ }^{[37]}$ and Flohe and Gunzler ${ }^{[38]}$, respectively. The activities of lactate dehydrogenase (LDH) and alkaline phosphatase (ALP) were estimated in the testicular supernatant using LDH (P-L) kit (Mod. IFCC method) and Beacon kit (PNPP kinetic method), respectively.

\section{Estimation of cholesterol and serum testosterone:}

The level of cholesterol was estimated in the $10 \%$ homogenate of the testis by using commercial diagnostic kit of Enzopak (Reckon Diagnostics Private Ltd.). Blood was collected by cardiac puncture immediately after sacrificing the animals. Serum was obtained by centrifuging the blood at $4500 \mathrm{rpm}$ for $20 \mathrm{~min}$ in a cooling centrifuge and stored at $-20^{\circ}$ until utilized. Level of serum testosterone was estimated by ELISA in the extracted steroid using LDN Kit.

\section{Mating ability and fertility:}

Six males of each group were separately caged with two virgin proestrus females for overnight. Mating ability of the males were assessed by the presence of vaginal plug in the female mice and the fertility of the same were assessed by observing the number of pregnant females on d 15 invaginal plug positive females.

\section{Statistical analysis:}

The values were represented as mean $\pm \mathrm{SE}$ in each group. All data were analysed statistically by one way ANOVA followed by Newman-Keul's test for comparison of the groups. Body weight was analysed using Student's t- test. Values were considered significant at $\mathrm{p}<0.05$.

\section{RESULTS AND DISCUSSION}

The qualitative tests performed on the root extract of $W$. somnifera showed the formation of persistent froth and emulsion, indicating the presence of saponin and appearance of yellow colour, indicating the presence of flavonoid (Table 1).

Oral administration of $100 \mathrm{mg} / \mathrm{kg} /$ day of $\mathrm{AlCl}_{3}$ alone in the mice of group II caused significant decrease in the final body weight, compared to their initial body weight. Forty two days after withdrawal of treatment in group III mice did not cause significant alteration in the final body weight, compared to their initial body weight, indicating reversal in the final body weight, compared to those of group I that served as control. The final body weight of the mice, administered with $200 \mathrm{mg} / \mathrm{kg} /$ day of $W$. somnifera to group IV mice remained unaffected, compared with their initial body weight. Co-administration of low dose $(100 \mathrm{mg} / \mathrm{kg} / \mathrm{day})$ of $W$. somnifera was not able to restore the final body weight loss in the mice administered with $100 \mathrm{mg} /$ $\mathrm{kg}$ /day of $\mathrm{AlCl}_{3}$. However, the final body weight loss was restored significantly to the control level in mice administered with $\mathrm{AlCl}_{3}(100 \mathrm{mg} / \mathrm{kg} /$ day $)$ and a high dose $(200 \mathrm{mg} / \mathrm{kg} /$ day) of $W$. somnifera (fig. 1).

Oral administration of only $\mathrm{AlCl}_{3}(100 \mathrm{mg} / \mathrm{kg} / \mathrm{d})$ to the mice of group II, caused significant decline in the weight of testis, compared to that of group I control. However, $42 \mathrm{~d}$ after withdrawal of the treatment in the mice of group III, caused a non-significant increase in the weight of the testis, compared to that of group II, administered with high dose $(100 \mathrm{mg} / \mathrm{kg} / \mathrm{d})$ of $\mathrm{AlCl}_{3}$. Administration of $W$. somnifera alone $(200 \mathrm{mg} / \mathrm{kg} / \mathrm{d})$ in the mice of group IV did not alter the testicular weight compared with the control. Co-administrations of $100 \mathrm{mg} / \mathrm{kg} / \mathrm{d} \mathrm{AlCl}_{3}$ and $100 \mathrm{mg} / \mathrm{kg} / \mathrm{d}$ of $W$. somnifera to the mice of group $\mathrm{V}$, did not restore the weight of the testis, compared to the control. However, the significantly reduced weight of the testis as noticed in group II, was significantly restored to the control values

\section{TABLE 1: QUALITATIVE ANALYSIS OF PHYTOCHEMICALS}

\begin{tabular}{llcc}
\hline \multirow{2}{*}{ Sample } & \multicolumn{2}{c}{ Phytochemicals } \\
\cline { 2 - 3 } & Saponin & Flavonoid \\
\hline $\begin{array}{l}\text { Ethanol root extract of Withania } \\
\text { somnifera }\end{array}$ & ++ & ++ \\
\hline++ Represents presence of phytochemicals & & \\
\hline
\end{tabular}


in the mice of group VI, which received $100 \mathrm{mg} / \mathrm{kg} / \mathrm{d}$ of $\mathrm{AlCl}_{3}$ and $200 \mathrm{mg} / \mathrm{kg} / \mathrm{d}$ of $W$. somnifera (fig. 2).

Testis of $100 \mathrm{mg} / \mathrm{kg} \mathrm{AlCl}$-treated group II mice exhibited noticeable degenerative changes (fig. 3) as indicated by shrinkage of the seminiferous tubules along with thinning of the tunica propria, vacuolization, loosening and disorganization of the germ cells. Lumina of majority of the seminiferous tubules in the testis of the mouse treated with this dose, were either devoid of spermatozoa or contained PAS stained cell debris. Regression of the Leydig cells were also noticed in the testis of such treated mice. Forty two days after withdrawal of $\mathrm{AlCl}_{3}$ treatment in group III mice resulted in partial recovery in majority of the seminiferous tubules as indicated by the proliferation of germ cells (fig. 3). However, few tubules still appeared regressed, their lumina were devoid of spermatozoa or having fewer spermatozoa. The regressed histoarchitecture of the Leydig cells were also not fully restored compared

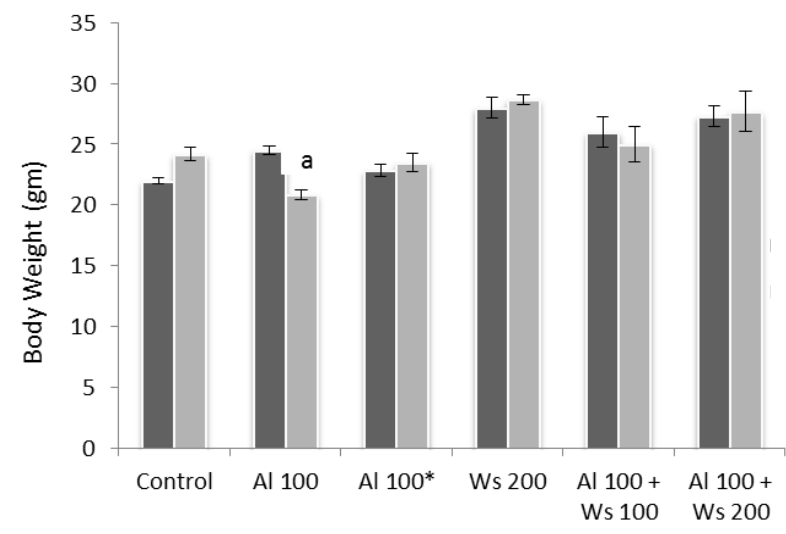

Fig. 1: Effects of treatments on the body weight of mice Effects of oral administration of $\mathrm{AlCl}_{3}, \mathrm{AlCl}_{3}{ }^{*}, W$. somnifera and administration of $\mathrm{AICl}_{3}$ along with low and high doses of $W$. somnifera on the body weight. ( $\square$ ) Initial body weight; ( $\square$ ) final

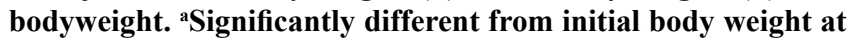
$\mathbf{p}<\mathbf{0 . 0 5}$

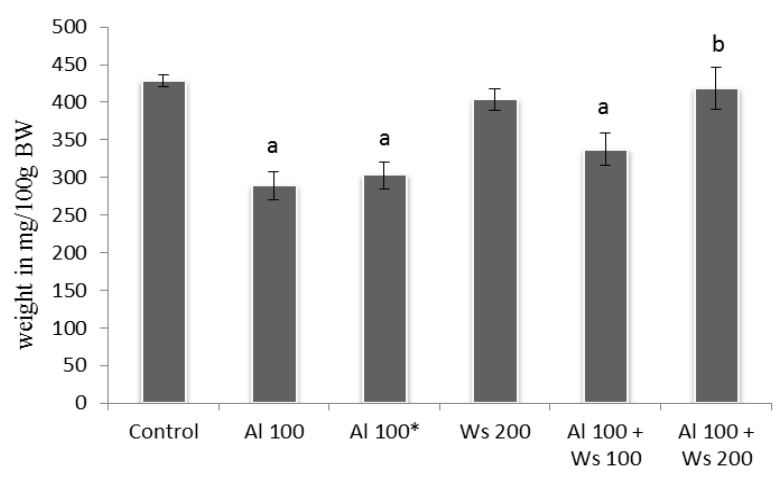

Fig. 2: Effect of various treatments on the weight of testis Effect of oral administration of $\mathrm{AlCl}_{3}, \mathrm{AlCl}_{3} *, W$. somnifera and co-administration of $\mathrm{AlCl}_{3}$ along with low and high doses of $W$. somnifera on the weight of testis asignificantly different from control, bsignificantly different from $\mathrm{AlCl}_{3}$ at $\mathbf{p}<0.05$ to the control. Administration of $200 \mathrm{mg} / \mathrm{kg} / \mathrm{d}$ of $W$. somnifera to the mice of group IV did not cause any alteration in the histological features of the testis (fig. 3), comparable to that of the control. $\mathrm{AlCl}_{3}$-induced regressive histological changes in the seminiferous tubules and the Leydig cells, as noticed in the testis of group II mice were still observed in some tubules of the testis of group $\mathrm{V}$ mice, indicating partial recovery (fig. 3). However, complete recovery was noticed in the spermatogenic activity and morphology of the Leydig cells, following co-administrations of $\mathrm{AlCl}_{3}$ and a high dose of $W$. somnifera to group VI mice (fig. 3 ).

Administration of $100 \mathrm{mg} / \mathrm{kg} / \mathrm{d}$ of $\mathrm{AlCl}_{3}$ to group II mice caused a significant increase in the concentration of testicular aluminium, compared to that of the control. However, $42 \mathrm{~d}$ after withdrawal of $\mathrm{AlCl}_{3}$ treatment in group III mice, a significant decrease in the concentration of the testicular aluminium was observed compared to that of the levels seen in group II administered with $100 \mathrm{mg} / \mathrm{kg}$ of $\mathrm{AlCl}_{3}$ for $30 \mathrm{~d}$, although the concentration of accumulated aluminium in the testis of the mice of this group was still significantly higher than the control. Administration of $W$. somnifera $(200 \mathrm{mg} / \mathrm{kg} / \mathrm{d})$ only did not affect the concentration of accumulated aluminium in the testis and was similar to that of the control. Co-administrations of $\mathrm{AlCl}_{3}$ with a low dose of $W$. somnifera to group $\mathrm{V}$ mice, was effective in decreasing the concentration of accumulated aluminium in the testis, compared to that of the group II, administered only with $100 \mathrm{mg} / \mathrm{kg} / \mathrm{d}$ of $\mathrm{AlCl}_{3}$, though it was still significantly higher than the control. However, $200 \mathrm{mg} / \mathrm{kg}$ of $W$. somnifera was more effective in reducing the concentration of accumulated aluminium in the testis in $\mathrm{AlCl}_{3}$-treated mice and showed significant reduction compared to that of group II mice administered only with $\mathrm{AlCl}_{3}$, hence attained the values similar to the control (fig. 4).

Administration of $\mathrm{AlCl}_{3}$ to group II mice resulted in a significant increase in the level of LPO, as indicated by the increased level of testicular MDA compared to that of the control of group I. Forty two days after withdrawal of the treatment to group III mice, an insignificant decrease in the level of LPO in the testis was observed compared to group II mice administered with $100 \mathrm{mg} / \mathrm{kg} / \mathrm{d}$ of $\mathrm{AlCl}_{3}$. The level of testicular LPO in group IV mice administered with $200 \mathrm{mg} / \mathrm{kg}$ $W$. somnifera only, was similar to that of the control. Group V mice co-administered with $100 \mathrm{mg} / \mathrm{kg} / \mathrm{d}$ of $\mathrm{AlCl}_{3}$ and $100 \mathrm{mg} / \mathrm{kg} / \mathrm{d}$ of $W$. somnifera, exhibited nonsignificant restoration by showing partial reinstatement 

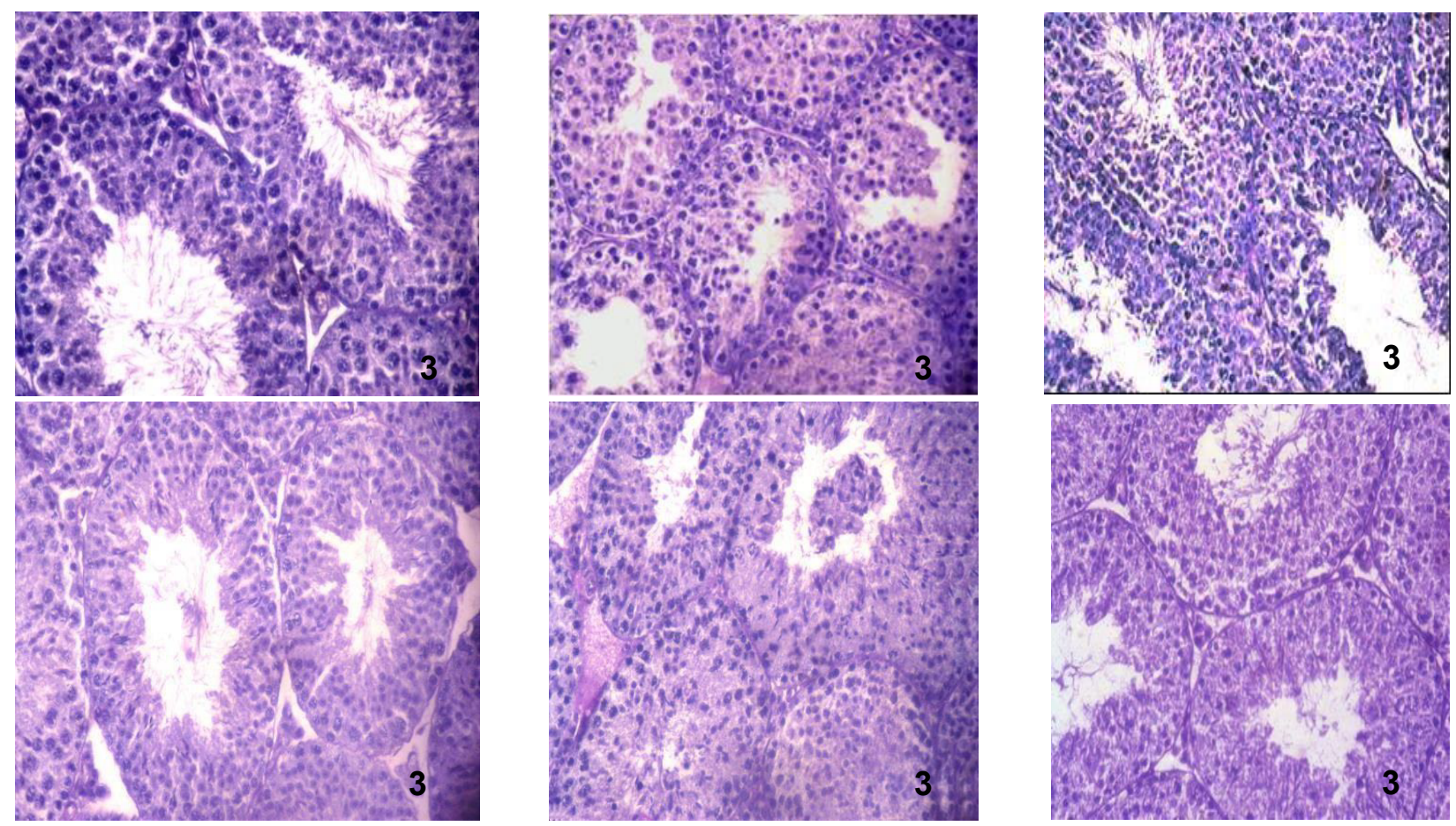

Fig. 3: Effects of $\mathrm{AlCl}_{3}$ and $W$. somnifera on testicular histology in mice

A. TS of the testis of a control mouse showing normal histological features. The seminiferous tubules exhibited full spermatogenic activity and normal morphology of the Leydig cells. B. TS of the testis of a mouse of group II administered with $100 \mathrm{mg} / \mathrm{kg} / \mathrm{d}$ of $\mathrm{AlCl}_{3}$ for $30 \mathrm{~d}$. Noticeable degenerative changes in the seminiferous tubules as indicated by thinning of the tunica propria, loosening and disorganization of the germ cells and lumen devoid of spermatozoa, along with regression of the Leydig cells. C. TS of the testis of a mouse of group III, treated with $100 \mathrm{mg} / \mathrm{kg} / \mathrm{d} \mathrm{of} \mathrm{AlCl}_{3}$ for $30 \mathrm{~d}$ and sacrificed $42 \mathrm{~d}$ after cessation of treatment. Spermatogenic activity recovered in a few seminiferous tubules while other tubules still presented inhibited spermatogenesis. Leydig cells are partially regressed. D. TS of the testis of a mouse of group IV, $200 \mathrm{mg} / \mathrm{kg} / \mathrm{d}$ of the root extract of $W$. somnifera, for $30 \mathrm{~d}$. Seminiferous tubules exhibited full spermatogenic activity with normal appearance of the Leydig cells. E. TS of the testis of a mouse of group $\mathrm{V}, \mathrm{AlCl}_{3}$ co-administered with low dose of $W$. somnifera for $30 \mathrm{~d}$. Regressive changes in some seminiferous tubules showed exfoliated germ cells in their lumina. Other tubules showed normal spermatogenic activity. Leydig cells also showed regressed morphology. F. TS of the testis of a mouse of group $\mathrm{VI}$, co-administered with $\mathrm{AlCl}_{3}$ and a high dose of W. somnifera for $30 \mathrm{~d}$. Complete recovery in spermatogenic activity indicated by well-organized and full population of the germ cells in the seminiferous tubules, lumen filled with spermatozoa and normal appearance of the Leydig cells. Magnification X40.

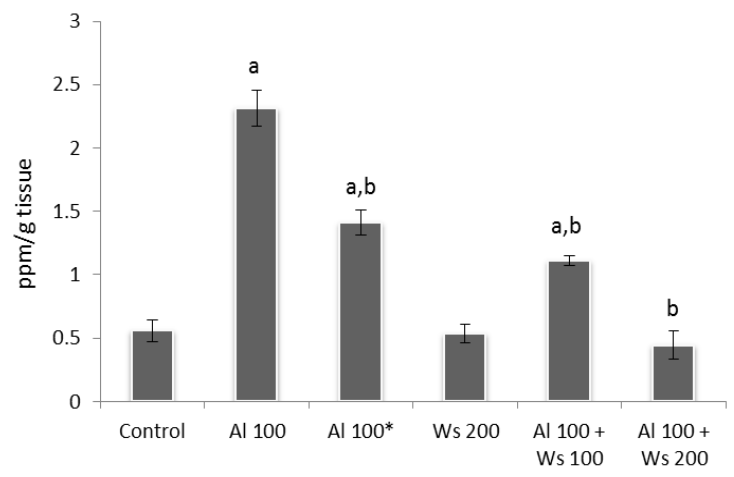

Fig. 4: Effect of various treatments on testicular aluminium accumulation

Effect of oral administration of $\mathrm{AlCl}_{3}, \mathrm{AlCl}_{3}{ }^{*}, W$. somnifera and co-administration of $\mathrm{AlCl}_{3}$ along with low and high doses of $W$. somnifera on the testicular aluminium accumulation. aSignificantly different from control, bsignificantly different from $\mathrm{AlCl}_{3}$-treated mice at $\mathbf{p}<0.05$

in the level of testicular LPO, compared to group II mice. However, co-administrations of $\mathrm{AlCl}_{3}$ with a high dose of $W$. somnifera to group VI mice caused complete restoration in the same by exhibiting significant reduction in the level of testicular LPO, compared to $\mathrm{AlCl}_{3}$-treated mice, hence attained the values similar to that of the control (Table 2).

Administration of $\mathrm{AlCl}_{3}$ caused significant decrease in the activity of testicular SOD, CAT and GPx compared to control. Treatment withdrawal (group III) did not restore the activity of these enzymes, while the levels increased slightly but not significantly compared to those of group II, which received only $\mathrm{AlCl}_{3}$. The activities of these antioxidant enzymes in the testis of group IV mice administered with $200 \mathrm{mg} / \mathrm{kg}$ of $W$. somnifera were also similar to those of the control. The mice of group V, co-administered with $100 \mathrm{mg} / \mathrm{kg}$ of $\mathrm{AlCl}_{3}$ and $100 \mathrm{mg} / \mathrm{kg}$ of $W$. somnifera, exhibited nonsignificant restoration by showing partially increased activity of SOD, CAT and GPx compared to that of group II mice. However, the altered activities of these three antioxidant enzymes were completely restored to the control values following co-administration of $\mathrm{AlCl}_{3}$ and $200 \mathrm{mg} / \mathrm{kg}$ of $W$. somnifera to the mice of group VI (Table 2). 
TABLE 2: EFFECT OF VARIOUS TREATMENTS ON TESTICULAR ANTIOXIDANT MARKERS IN MICE

\begin{tabular}{lcccc}
\hline Groups and treatment & $\begin{array}{c}\text { MDA } \\
\text { (nmol/mg protein) }\end{array}$ & $\begin{array}{c}\text { SOD } \\
\text { (Unit/mg protein) }\end{array}$ & $\begin{array}{c}\text { CAT } \\
\text { ( } \begin{array}{c}\text { Gmol/min/mg } \\
\text { protein) }\end{array}\end{array}$ & $\begin{array}{c}18.918 \pm 2.609 \\
\text { (Unit/mg protein) }\end{array}$ \\
\hline I: Control & $0.258 \pm 0.038$ & $1.638 \pm 0.141$ & $0.100 \pm 0.016$ \\
II: Al100 & $0.518 \pm 0.026^{\mathrm{a}}$ & $0.957 \pm 0.204^{\mathrm{a}}$ & $7.788 \pm 0.097^{\mathrm{a}}$ & $0.014 \pm 0.006^{\mathrm{a}}$ \\
III: Al100* & $0.483 \pm 0.056^{\mathrm{a}}$ & $1.032 \pm 0.202^{\mathrm{a}}$ & $9.822 \pm 0.568^{\mathrm{a}}$ & $0.032 \pm 0.006^{\mathrm{a}}$ \\
IV: W. somnifera 200 & $0.262 \pm 0.025$ & $1.590 \pm 0.089$ & $18.031 \pm 1.513$ & $0.091 \pm 0.006$ \\
V: Al 100+ W. somnifera 100 & $0.449 \pm 0.033^{\mathrm{a}}$ & $1.182 \pm 0.142^{\mathrm{a}}$ & $10.669 \pm 1.547^{\mathrm{a}}$ & $0.036 \pm 0.009^{\mathrm{a}}$ \\
VI: Al 100+ W. somnifera 200 & $0.272 \pm 0.036^{\mathrm{b}}$ & $1.559 \pm 0.091^{\mathrm{b}}$ & $17.932 \pm 1.205^{\mathrm{b}}$ & $0.114 \pm 0.019^{\mathrm{b}}$ \\
\hline
\end{tabular}

Effect of oral administration of $\mathrm{AlCl}_{3}, \mathrm{AlCl}_{3}{ }^{*}$,W. somnifera and co-administration of $\mathrm{AlCl}_{3}$ along with low and high doses of W. somnifera on the testicular antioxidant markers. Values are mean $\pm \mathrm{SE}$ of 6 animals, asignificantly different from control, bsignificantly different from $\mathrm{AlCl}_{3}$ at $\mathrm{p}<0.05$

The activities of LDH and ALP in the testis exhibited significant increase in group II mice compared to the control. Forty two days after withdrawal of the treatment (group III) did not restore the activities of LDH and ALP significantly to the control value, compared to group II mice. The activities of these enzymes in the testis of group IV administered with $200 \mathrm{mg} / \mathrm{kg} \mathrm{W}$. somnifera only, were similar to that of the control. Co-administration of $100 \mathrm{mg} / \mathrm{kg}$ of $\mathrm{AlCl}_{3}$ and $100 \mathrm{mg} / \mathrm{kg}$ of $W$. somnifera (group V) exhibited non-significant restoration by showing partial decline in the activity of testicular LDH and ALP, compared to that of group II mice. However, co-administrations of $100 \mathrm{mg} / \mathrm{kg}$ of $\mathrm{AlCl}_{3}$ and $200 \mathrm{mg} / \mathrm{kg}$ of $W$. somnifera to group VI mice resulted in complete restoration by exhibiting significant reduction in the activities of these two enzymes, compared only with mice of group II, hence attained the values similar to that of the control (fig. 5).

Level of cholesterol in the testis of in group II mice was significantly increased, compared to the control. Forty two days after withdrawal of $\mathrm{AlCl}_{3}$ treatment caused an insignificant decrease in the level of testicular cholesterol, compared to that of group II mice. The level of testicular cholesterol in $200 \mathrm{mg} / \mathrm{kg}$ of $W$. somnifera-treated group IV mice similar to that of the control. Co-administrations of $\mathrm{AlCl}_{3}$ and $100 \mathrm{mg} /$ $\mathrm{kg} \mathrm{W}$. somnifera (group V) exhibited partially reduced level of the cholesterol compared to that of group II mice. However, complete restoration in the testicular cholesterol level was noticed in group VI mice co-administered with $100 \mathrm{mg} / \mathrm{kg} \mathrm{AlCl}$ and $200 \mathrm{mg} / \mathrm{kg}$ of $W$. somnifera, compared to group II mice (fig. 6).

Administration of $\mathrm{AlCl}_{3}$ to group II mice caused a significant decrease in the level of serum testosterone compared to the control. Forty two days after withdrawal of the treatment in group III mice caused an insignificant restoration in the level of serum
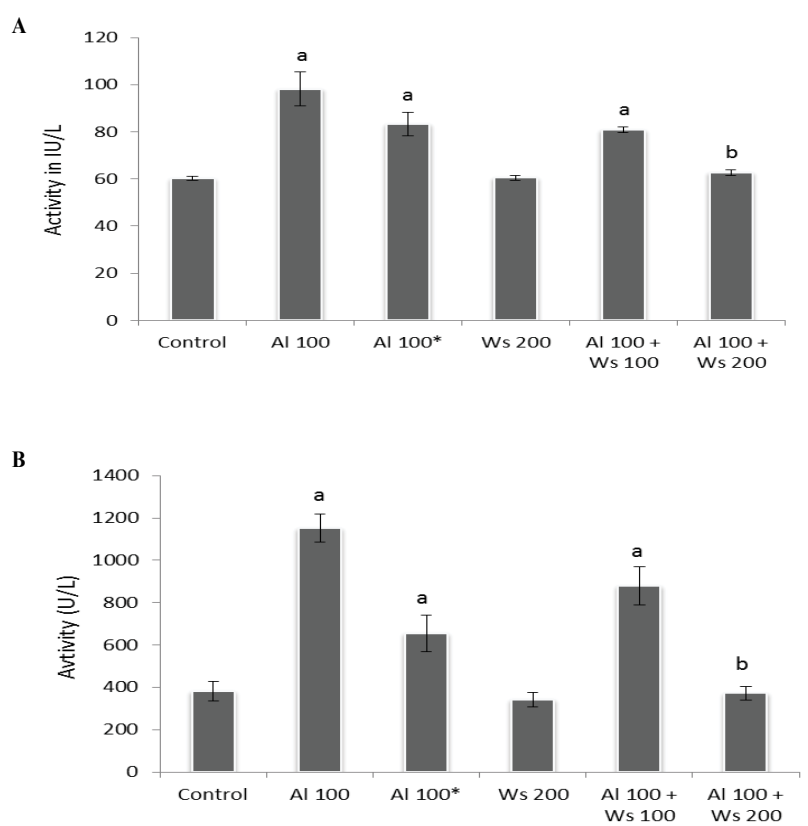

Fig. 5: Effect of various treatments on testicular LDH and ALP activities

Effect of oral administration of $\mathrm{AlCl}_{3}, \mathrm{AlCl}_{3}$, W. somnifera and co-administration of $\mathrm{AlCl}_{3}$ along with low and high doses of $W$. somnifera on the activity of testicular A. LDH and B. ALP. aSignificantly different from control, ${ }^{b}$ significantly different from $\mathrm{AlCl}_{3}$-treated mice at $\mathbf{p}<0.05$

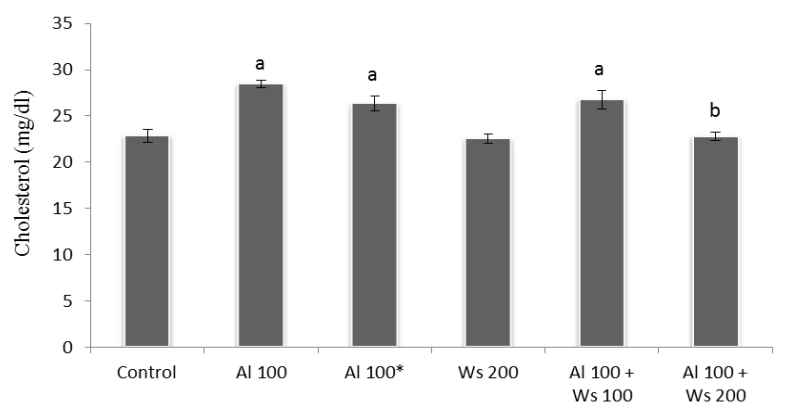

Fig. 6: Effects of various treatments on testicular cholesterol levels

Effects of oral administration of $\mathrm{AlCl}_{3}, \mathrm{AlCl}_{3}$ *, W. somnifera and co-administration of $\mathrm{AlCl}_{3}$ along with low and high doses of $W$. somnifera on the concentration of testicular cholesterol. a Significantly different from control, ${ }^{b}$ significantly different from $\mathrm{AlCl}_{3}$-treatmed mice at $\mathbf{p}<0.05$ 
testosterone. The level of serum testosterone was unaltered by treatment with $200 \mathrm{mg} / \mathrm{kg} \mathrm{W}$. somnifera to group IV mice. Co-administrations of $\mathrm{AlCl}_{3}$ and $100 \mathrm{mg} / \mathrm{kg}$ of $W$. somnifera (group V) produced only an insignificant restoration, while complete restoration of serum testosterone levels were produced by the co-administration of $200 \mathrm{mg} / \mathrm{kg}$ of $W$. somnifera along with $\mathrm{AlCl}_{3}$ to group IV mice (fig.7).

Mating ability and fertility of male mice of control and $200 \mathrm{mg} / \mathrm{kg} \mathrm{W}$. somnifera -treated groups were not altered. However, only two male mice from group II $\left(100 \mathrm{mg} / \mathrm{kg}\right.$ of $\left.\mathrm{AlCl}_{3}\right)$ mated with two female in respective cages and out of 12 females only these 2 mated females got impregnated. In the withdrawal group (group III), out of twelve females, 5 mated with 3 male mice in respective cages and out of these, 4 mice get impregnated. In group VI mice $\left(\mathrm{AlCl}_{3}\right.$ $+200 \mathrm{mg} / \mathrm{kg}$ of $W$. somnifera) mating ability and fertility of male mice was found to be almost similar to that of the control group. In this group all males were mated with female in respective cages and out of 12 females, 10 were impregnated (Table 3 ).

In Ayurveda, $W$. somnifera is claimed to possess potent aphrodisiac and antioxidant property, as it contains saponin and several flavonoids, respectively ${ }^{[24]}$. These phytochemicals may vary in the medicinal plants of the same species collected from different regions and also in different parts of the same plant ${ }^{[39,40]}$. Therefore,

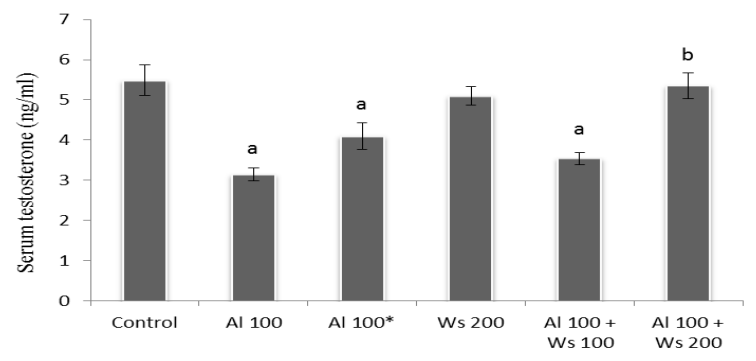

Fig. 7: Effects of various treatments on serum testosterone levels Effects of oral administration of $\mathrm{AlCl}_{3}, \mathrm{AlCl}_{3}{ }^{*}, W$. somnifera and co-administration of $\mathrm{AlCl}_{3}$ along with low and high doses of $W$. somnifera on the level of serum testosterone. a'Significantly different from control, bsignificantly different from $\mathrm{AlCl}_{3}$ treated mice at $\mathbf{p}<0.05$ in the present study, quantitative analysis of the root of $W$. somnifera available in Varanasi was carried out after proper authentication and the analysis indicated presence of medicinally-active constituents such as saponins and flavonoids. Many authors have also reported the presence of saponin and flavonoid in W. somnifera ${ }^{[33,41,42]}$

Result of this investigation indicated that $200 \mathrm{mg} / \mathrm{kg} /$ day of the root extract of $W$. somnifera was able to significantly restore the final body weight of the mice which was significantly decreased in $\mathrm{AlCl}_{3}$-treated mice. This is in contrast to the finding of Singh et al. ${ }^{[43]}$, who reported the anabolic action of $W$. somnifera by observing a significant increase in the body weight of the $W$. somnifera-treated rat for the period of $3 \mathrm{mo}$. In present study, extract of $W$. somnifera also showed positive result toward saponin, possessing anabolic action that might have restored the $\mathrm{AlCl}_{3}$-induced reduction in the body weight.

Co-administration of $200 \mathrm{mg} / \mathrm{kg}$ of $W$. somnifera along with $100 \mathrm{mg} / \mathrm{kg}$ of $\mathrm{AlCl}_{3}$ significantly restored the relative weights of testis that were reduced significantly after treatment with only $100 \mathrm{mg} / \mathrm{kg}$ of $\mathrm{AlCl}_{3}$. Similar results were reported by Prithiviraj et al. ${ }^{[29]}$, a significant improvement in the weight of testis following administration of $100 \mathrm{mg} /$ $\mathrm{kg}$ of $W$. somnifera for $30 \mathrm{~d}$ in $2.5 \mathrm{mg} / \mathrm{kg}$ cadmium chloride-treated rats. Significant improvement in the weight of testis was also reported by Borde et al. ${ }^{[44]}$ in cadmium chloride (200 ppm/day) along with $W$. somnifera (500 ppm)-exposed rat for $60 \mathrm{~d}$, indicating stimulatory effect of $W$. somnifera on the development and functional activity of the male reproductive system. Kumar and Singh ${ }^{[32]}$ have also reported the recovery in testicular weight of EGME $(600 \mathrm{mg} / \mathrm{kg})$-treated mice after administration of $W$. somnifera $(100 \mathrm{mg} / \mathrm{kg} / \mathrm{d})$. It also may be due to the presence of sitoindoside and withanolides, steroid saponins in $W$. somnifera that are responsible for restoration in the population of the germ cells in the testis, leading to the recovery in the weight of the testis ${ }^{[45]}$. Thus the existence of saponin,

TABLE 3: EFFECT OF VARIOUS TREATMENTS ON THE MATING ABILITY AND FERTILITY IN MICE

\begin{tabular}{|c|c|c|c|c|c|c|}
\hline \multirow{2}{*}{ Groups } & \multicolumn{3}{|c|}{ Male } & \multicolumn{3}{|c|}{ Female } \\
\hline & Tested & Mated & Fertile & Tested & Mated & Pregnant \\
\hline Gr. I: Control & 6 & 6 & 12 & 12 & 12 & 12 \\
\hline Gr. II: Al 100 & 6 & 2 & 2 & 12 & 2 & 2 \\
\hline Gr. III: Al 100* & 6 & 3 & 3 & 12 & 5 & 4 \\
\hline Gr. IV: W. somnifera 200 & 6 & 6 & 6 & 12 & 12 & 12 \\
\hline Gr. VI: Al 100+ W. somnifera 200 & 6 & 6 & 5 & 12 & 10 & 10 \\
\hline
\end{tabular}

Effect of oral administration of $\mathrm{AlCl}_{3}, \mathrm{AlCl}_{3}{ }^{*}, w$. Somnifera and co- administration of $\mathrm{AlCl}_{3}$ and high dose of w. Somnifera on the mating ability and fertility 
proved through quantitative analysis of the root extract of $W$. somnifera is probably involved in restoration of testicular weight. In the present study, regressive changes such as shrinkage of the seminiferous tubules along with thinning of tunica propria, vacuolization, loosening, disorganization and necrosis of the germ cells with tubular lumina either devoid of spermatozoa or contained PAS stained cell debris and atrophy in the Leydig cells were observed in the testis of $\mathrm{AlCl}_{3}$-treated mice, resulting in the suppression of spermatogenic activity. Results of the study also indicated that administration of $200 \mathrm{mg} / \mathrm{kg}$ of $W$. somnifera in $\mathrm{AlCl}_{3}$-treated mice was effective enough to protect the seminiferous tubules and the Leydig cells in the testis. The protection of spermatogenic activity by $W$. somnifera, might be due to androgenic and antioxidative properties of this plant ${ }^{[46-49]}$. Histological abnormalities observed in the seminiferous tubules and the Leydig cells after treatment with sodium arsenite for $45 \mathrm{~d}$ have been reported to be ameliorated by treatment with $100 \mathrm{mg} / \mathrm{kg}$ of $W$. somnifera for $30 \mathrm{~d}^{[50]}$. According to these authors ameliorating properties of $W$. somnifera might be due to the sitoindosides VII-X and withaferin, which bear antioxidative properties and help to protect the testicular tissues from free radicals. In present study existence of saponin and flavonoids are noticed by qualitative analysis of the root extract of $W$. somnifera. The flavonoids act as scavengers of various oxidizing species while the saponins maintain the normal level of a hormone, testosterone, hence ameliorating $\mathrm{AlCl}_{3}$ induced histopathological alterations in the testis. Oral administration of $\mathrm{AlCl}_{3}$ at a dose of $100 \mathrm{mg} / \mathrm{kg} / \mathrm{d}$ for $30 \mathrm{~d}$ resulted in significant increase in the concentration of aluminium in the testis. Aluminium might have entered in high concentration in the testis of the treated mice by interrupting the blood-testis barrier. Metal chelating properties and the presence of several antioxidants in plants like vitamin $\mathrm{E}$, vitamin $\mathrm{C}$, glutathione, coenzyme Q10 and natural polyphenols such as flavonoids and phenolic acids provide strength to the blood-testis barrier by reducing the damage caused by the free radicals ${ }^{[51]}$. Presence of these antioxidants in $W$. somnifera might have reduced the aluminium accumulation in the testis of the mice co-administered with $\mathrm{AlCl}_{3}$ and $200 \mathrm{mg} / \mathrm{kg}$ of $W$. somnifera. Alam et al. ${ }^{[52]}$ have also reported the binding capacity of $W$. somnifera extract with metal ion and produce metal-chelator complex and existence of flavonoids in extract bearing antioxidant properties, which might have stabilized the blood-testis barrier resulting in the reduction of the metal entry into the testis. Normal level of testosterone, reported in present study, may also protect the Sertoli cells that play a crucial role in the regulation of Sertoli cells tight junction-permeability barrier and reduces the chances of metal entry in testis.

It has been reported previously that $W$. somnifera possessed potent antioxidant activity and treatment with this plant could counteract the formation of ROS in infertile men $^{[26]}$. It has also been shown that the active principles of $W$. somnifera such as sitoindosides VII-X and glycowithanolides (withaferin A) reactivate the major free radical scavenging enzymes ${ }^{[46,53,54]}$. In the present study, co- administration of $200 \mathrm{mg} / \mathrm{kg}$ of $W$. somnifera with $\mathrm{AlCl}_{3}$ to mice for $30 \mathrm{~d}$ restored the level of MDA and the activities of SOD, CAT and GPx to their control values. Prithviraj et al. ${ }^{[29]}$ have reported similar finding in the testis of cadmium-treated rat, supplemented with the root extract of $W$. somnifera $(100 \mathrm{mg} / \mathrm{kg})$. Likewise Patil et al. ${ }^{[28]}$ and Kumar et $a l .{ }^{[30]}$ have reported the efficacy of ethanol extracts of leaves and root of $W$. somnifera in reducing the level of lipid peroxidation in D-galactose-treated mouse and arsenic-treated rat, respectively. Even in infertile men also, treatment with $W$. somnifera $(5 \mathrm{~g} / \mathrm{d})$ improves the activities of SOD, CAT and glutathione, eventually by reducing the levels of LPO and protein carbonyl groups. In this way the $W$. somnifera neutralizes the free radical generation to reduce MDA formation, as it contains many flavonoids, amino acids and withanoloids ${ }^{[55]}$. Qualitative test performed in the present study showed the existence of flavonoids in the root extract of $W$. somnifera, which are reported to possess high antioxidative and lipid peroxidation inhibiting properties ${ }^{[52]}$. Hence, the protective effects of this root extract on antioxidant system may be attributed to the existence of flavonoids. The restored activities of testicular LDH and ALP following co-administrations of W. somnifera $(200 \mathrm{mg} / \mathrm{kg})$ with $\mathrm{AlCl}_{3}$ $(100 \mathrm{mg} / \mathrm{kg})$ to the control level indicated the effectiveness of $W$. somnifera to prevent the damage and to inhibit the leakage of the enzymes through the cellular membrane. Surana et al. ${ }^{[56]}$ have reported the protective effect of root extract of $W$. somnifera $(200$ $\mathrm{mg} / \mathrm{kg} / \mathrm{d}$ for $15 \mathrm{~d}$ ) against quinalphos $(14 \mathrm{mg} / \mathrm{kg} / \mathrm{d})$ induced alterations in serum LDH and ALP in the rat. According to Surana et al. ${ }^{[56]}$, it could probably be due to the presence of antioxidants in the extract of $W$. somnifera. The significant restorations in the activities of LDH and ALP as noticed in the present study indicate the protective effects of $200 \mathrm{mg} / \mathrm{kg} / \mathrm{d}$ of the root extract of $W$. somnifera against $\mathrm{AlCl}_{3}$ induced degeneration in the seminiferous tubules. This 
protective mechanism may be attributed to the presence of flavonoids and other phytochemicals present in the extract of $W$. somnifera which have antioxidant property and having potential to scavenge the free radicals. In the present study the significantly reduced level of serum testosterone as noticed in $\mathrm{AlCl}_{3}$-treated mice is restored to the control value in those animals co-administered with $200 \mathrm{mg} / \mathrm{kg}$ of $W$. somnifera with $\mathrm{AlCl}_{3}$. Consistent findings were reported by Kumar et al. ${ }^{[30]}$, indicating the restoration in the level of serum testosterone in the rat co-administered with $100 \mathrm{mg} / \mathrm{kg}$ of $W$. somnifera extract and arsenic $(8 \mathrm{mg} / \mathrm{kg} / \mathrm{d})$ for $30 \mathrm{~d}$. In a clinical study, consumption of $W$. somnifera $(5 \mathrm{~g} / \mathrm{d})$ for 3 mo significantly improved the level of serum testosterone in infertile $\operatorname{men}^{[25]}$. In the present study, existence of saponin, in the root extract of $W$. somnifera, analysed qualitatively might have increased the level of serum testosterone. The restored level of serum testosterone, as noticed in the co-administered mice (group VI), could be correlated with the reduced level of testicular cholesterol that is also reported in this study, as it is precursor of testosterone. Traditionally, in Ayurveda, W. somnifera is used as rejuvenative tonic ${ }^{[57,58]}$ and male reproductive health booster ${ }^{[26]}$. In the present study, restoration in the mating ability of the male mice and fertility in female mice, impregnated with co-administered male mice suggest the beneficial properties of the root extract of $W$. somnifera on the level of serum testosterone and oxidative status. Beneficial effects of $W$. somnifera in male infertility have been reported by several authors ${ }^{[25,26,59]}$. According to these authors, it may be due to improvement in semen quality and regulation in the levels of reproductive hormones and oxidative stress by $W$. somnifera. In present study improved libido, sexual function and fertility in the mice may be due to presence of saponins and flavonoids in the root extract, implicated in restoring the level of serum testosterone and oxidative status of the testis, respectively.

In the present study, root extract of $W$. somnifera reduced the extent of aluminium chloride-induced testicular injury by reducing the aluminium accumulation, maintaining the activities of antioxidants in the testis and restoring the level of serum testosterone, indicating that $W$. somnifera has beneficial role in testicular functions leading to enhance the male fertility in the mice.

\section{Acknowledgements:}

Authors thank the University Grants Commission and
Banaras Hindu University for financial assistance to carry out the present work.

\section{Conflicts of interest:}

There are no conflicts of interest.

\section{REFERENCES}

1. Chowdhury AR. Recent Advances in Heavy Metals Induced Effect on Male Reproductive Function-A Retrospective. Al Ame En J Med Sci 2009;2:37-42.

2. Mathur N, Pandey G, Jain GC. Male Reproductive Toxicity of some selected metals: A Review. J Biol Sci 2010;10:396-404.

3. Pizent A, Tariba B, Zivkovic T. Reproductive toxicity of metals in men. Arh Hig Rada Toksikol 2012;63:35-46.

4. Abbasali KM, Zhila T, Farshad N. Developmental toxicity of aluminium from high doses of $\mathrm{AlCl}_{3}$ in mice. J Appl Res 2005;5:575-79.

5. Bondy SC. The neurotoxicity of environmental aluminum is still an issue. Neurotoxicol 2010;31:575-81.

6. Kawahara M, Kato-Negishi M. Link between Aluminum and the Pathogenesis of Alzheimer's Disease: The Integration of the Aluminum and Amyloid Cascade Hypotheses. Int J Alzheimer's Dis 2011;2011:1-17.

7. Turgut S, Bor-Kucukatay M, Emmungil G, Atsak P, Turgut G. The Effects of Low Dose Aluminum on Hemorheological and Hematological Parameters in Rats. Arch Toxicol 2007;81:11-7.

8. Chinoy NJ, Sharma AK, Patel TN, Memon R, Jhala DD. Recovery from fluoride and aluminium induced free radical liver toxicity in mice. Fluoride 2004;37:257-63.

9. Al-Qayim, Majida AJ, Saadoon D. Assessment of the ameliorative role of proplis and malic acid in intestinal and liver functions of aluminum exposed male rats. Int J Sci Nat 2013;4:552-58.

10. Shelley R, Kim NS, Parsons PJ, Lee BK, Jaar B, Fadrowski J, et al . Associations of multiple metals with kidney outcomes in lead workers. Occup Environ Med 2012;69:727-35.

11. Yousef, MI, Salama AF. Propolis protection from reproductive toxicity caused by aluminium chloride in male rats. Food and Chem Toxicol 2009;47:1168-75.

12. Pandey G, Jain GC. A review on toxic effects of aluminium exposure on male reproductive system and probable mechanisms of toxicity. Int $\mathrm{J}$ Toxico Appl Pharmacol 2013;3:48-57.

13. Muselin F, Cristina RT, Violeta IGNA, Dumitrescu E, Brezovan $\mathrm{D}$, Alexandra TRIF. The consequences of aluminium intake on reproductive function in male rats: a three-generation study. Turk J Med Sci 2016;46:1240-48.

14. Pandey G, Jain GC. Aluminium Chloride-Induced Testicular Effects in Rats: A Histomorphometrical Study. Asian J Applied Sci Tech 2017;1:46-52.

15. Chinoy NJ, Momin R, Jhala, DD. Fluoride and aluminium induced toxicity in mice epididymis and its mitigation by vitamin C. Res Reproduct 2005;38:115-21.

16. Mayyas I, Elbetieha A, Khamas W, Khamas WA. Evaluation of reproductive and fertility toxic potential of aluminium chloride on adult male mice. J Anim Vet Adv 2005;4;224-33.

17. Guo C, Huang CJ, Yeh MS, Hsu GSW. Aluminum induced suppression of testosterone through nitric oxide production in male mice. Environ Toxicol Pharmacol 2005;19:33-40. 
18. Guo $\mathrm{C}, \mathrm{Lu} \mathrm{Y}, \mathrm{Hsu} \mathrm{GSW}$, The influence of aluminum exposure on male reproduction and offspring in mice. Environ Toxicol Pharmacol 2005;20:135-41.

19. Hala AH, Inas K, Abdallaha ZA, Kamel GM. Grape seed extract alleviate reproductive toxicity caused by aluminium chloride in male rats. J Am Sci 2010;6:1200-09.

20. Kumar P, Singh P. Protective Role of Tribulus Terrestris on Aluminium Chloride - Induced Reproductive Toxicity in the Male Laboratory Mouse. Int J Pharm Sci Res 2015;6:23952405.

21. Kumar P, Singh P. Tribulus terrestris ameliorates aluminium chloride - induced alterations in oxidative status and functional markers in the liver, kidney, brain and testis of the laboratory mouse. Indian J Biochem Biophy 2016;53:179-86.

22. Gurib-Fakim A. Medicinal plants: traditions of yesterday and drugs of tomorrow. Mol Aspects Med 2006;27:1-93.

23. Verma SK, Kumar A. Therapeutic uses of Withania somnifera (ashwagandha) with a note on withanolides and its pharmacological actions. Asian J Pharm Clin Res 2011;4:1-4.

24. Bhattacharya A, Ghosal S, Bhattacharya SK. Anti-oxidant effect of Withania somnifera glycowithanolides in chronic footshock stress-induced perturbations of oxidative free radical scavenging enzymes and lipid peroxidation in rat frontal cortex and striatum. J Ethnopharmacol 2001;74:1-6.

25. Ahmad MK, Mahdi AA, Shukla KK, Islam N, Rajender S, Madhukar D, et al. Withania somnifera improves semen quality by regulating reproductive hormone levels and oxidative stress in seminal plasma of infertile males. Fertil Steril 2010;94:98996.

26. Mahdi AA, Shukla KK, Ahmad MK, Singh R, Shankhwar SN, Singh V, et al. Withania somnifera Improves Semen Quality in Stress-Related Male Fertility. J Evid Based Complementary Altern Med 2011;2011:1-9.

27. Singh G, Sharma PK, Dudhe R, Singh S. Biological activities of Withania somnifera. Annals Biol Res 2010;1:56-63.

28. Patil RB, Vora SR, Pillai MM. Protective effect of spermatogenic activity of Withania somnifera (Ashwagandha) in galactose stressed mice. Ann Biol Res 2012;3:4159-65.

29. Prithiviraj E, Suresh S, Lakshmi NV, Mohanraj KG. Protective effect of Withania somnifera (Linn.) on cadmium-induced oxidative injury in rat testis. Phytopharmacol 2013; 4:269-90.

30. Kumar A, Kumar R, Rahman MS, Iqubal MA, Anand G, Niraj $\mathrm{PK}$, et al. Phytoremedial effect of Withania somnifera against arsenic-induced testicular toxicity in Charles Foster rats. Avicenna J Phytomed 2015;5:355-64.

31. Bhargavan, D, Deepa B, Shetty H, Krishna AP. The protective effect of Withania somnifera against oxidative damage caused by ethanol in the testes of adult male rats. Int $\mathrm{J}$ Basic Clin Pharmacol 2015;4:1104-08.

32. Kumar P, Singh P. Delayed response of epididymal sperm characteristics and testicular oxidative stress following EGME exposure: Ameliorating potential of Withania somnifera root extract. J App Pharm Sci 2018;8:122-28.

33. Ansari AQ, Ahmed SA, Waheed MA, Sayyed JA. Extraction and determination of antioxidant activity of Withania somnifera Dunal. Eur J Exp Bio 2013;3:502-07.

34. Edeoga HO, Okwu D, Mbaebie BO. Phytochemical constituents of some Nigerian Medicinal plants. Afri J Biotechnol 2005;4:685-88.

35. Okhawa H, Ohishi N, Yagi K. Assay of lipid peroxide in animal tissue by Thiobarbituric Acid Reaction. Anal Biochem 1979;95:351-58.

36. Marklund $\mathrm{S}$ and Marklund $\mathrm{G}$. Involvement of superoxide anion radical in antioxidation of pyrogallol and a constituent assay for superoxide dismutase. Eur J Biochem 1974;47:469-74.

37. Claiborne A. Catalase activity, In: Greenwald R, editors. CRC Handbook of Methods for Oxygen Radical Research. Boca Raton, Florida; CRC Press; 1985. p. 283-84.

38. Flohe L, Gunzler WA, Assay of glutathione peroxidase, In: Packer L, editors. Methods Enzymol. New York: Academic Press; 1984;105:114-21.

39. Abdul Kabir KA, Palwasha A, Ayeesha M, Safdar, AK, Rasool BT. Response of plant parts and age on the distribution of secondary metabolites on plants found in Quetta. Pak J Bot 2009;41:2129-35.

40. Kumar A, Bhardwaj A. Comparative, qualitative and quantitative chemotypic characterization among North India Tribulus terrestris. Int Res J Pharm 2012;3:212-18.

41. Chaudhuri D, Ghate1 NB, Sarkar R, Mandal, N. Phytochemical analysis and evaluation of antioxidant and free radical scavenging activity of Withania somnifera root. Asian J Pharm Clin Res 2012;5:193-99.

42. Bashir HS, Mohammed AM, Magsoud AS, Shaoub AM. Isolation of three flavonoids from Withania somnifera leaves (Solanaceae) and their antimicrobial activities. J For Prod Indus 2013;2:39-45.

43. Singh N, Bhalla M, de Jager P, Gilca M. An Overview on Ashwagandha: A Rasayana (Rejuvenator) of Ayurveda. Afr J Tradit Complement Altern Med 2011;8:208-13.

44. Borde AU, Athawaley AM, Mendhe MS, Patil MK, Lokhande PR, Jaiswal SA. Ameliorating potential of Ashwagandha on cadmium chloride induced changes in weights of visceral organs. Vet World 2008;1:343-45.

45. Ganzera M, Choudhary MI, Khan IA. Quantitative HPLC analysis of withanolides in Withania somnifera. Fitotherapia 2003;74:68-76.

46. Mishra L, Singh B, Dagenais S. Scientific basis for therapeutic use of Withania somnifera (Ashwagandha): A review. Altern Med Rev 2000;5:335-46.

47. Singh B, Saxena AK, Chandan BK, Gupta DK, Bhutani KK, Anand KK. Adaptogenic activity of a novel withanolide-free aqueous fraction from the roots of Withania somnifera Dun. Phytother Res 2001;15:311-18.

48. Uddin Q, Samiulla L, Singh VK, Jamil SS. Phytochemical and Pharmacological Profile of Withania somnifera Dunal: A Review. J Appl Pharm Sci 2012;2:170-75.

49. Gavande K, Jain K, Mehta R. Few medicinal activities of Ashwagandha (Withania somnifera). Int J Pharm Life Sci 2014;5:3603-06.

50. Kumar A, Kumar R, Rahman MS, Iqubal MA, Anand G, Niraj $\mathrm{PK}$, et al. Phytoremedial effect of Withania somnifera against arsenic-induced testicular toxicity in Charles Foster rats. Avicenna J Phytomed 2015;5:355-64.

51. Ouladsahebmadarek E, Giasi GS, Khaki A, Ahmadi Y, Farzadi L, Ghasemzadeh A, et al. The Effect of Compound Herbal Remedy Used in Male Infertility on Spermatogenesis and Pregnancy Rate. IJWHR 2016;4:185-88.

52. Alam N, Hossain M, Mottalib MA, Sulaiman SA, Gan SH, Khalil MI. Methanolic extracts of Withania somnifera leaves, fruits and roots possess antioxidant properties and antibacterial activities. BMC Complement Altern Med 2012;12:1-8.

53. Gupta Girdhari Lal, Rana AC. Withania somnifera (Ashwagandha): A Review. Pharmacognosy Review 2007;1:129-36.

54. Ashok GA, Shende MB, Chothe DS. Antistress activity of 
Ashwagandha (Withania somnifera)-A Review. Intr Ayurvedic Med J 2014;2:386-93.

55. Dhuley JN. Adaptogenic and cardioprotective action of ashwagandha in rats and frogs. J Ethnopharmacol 2000;70:5763.

56. Surana B, Mehta J, Seshadri S. Toxicological Effects of Quinalphos and its Subsequent Reversal by Using Root Extract of Withania somnifera and Leaf Pulp of Aloe barbadensis. J Indian Soc Toxicol 2008;4:1-5.

57. Upton R. American Herbal Pharmacopoeia and Therapeutic
Compendium: Ashwagandha Root (Withania somnifera)Standards of Analysis, Quality Control, and Therapeutics. Santa Cruz (CA): AHP; 2000.

58. Sukh Dev. Prime Ayurvedic Plant Drugs. Tunbridge Wells (UK): Anshan; 2005.

59. Gupta A, Mahdi AA, Shukla KK, Ahmad MK, Bansal N, Sankhwar P, et al. Efficacy of Withania somnifera on seminal plasma metabolites of infertile males: a proton NMR study at 800 MHz. J Ethnopharmacol 2013;149: 208-14. 